\author{
Katarzyna Sawicka-Mierzyńska \\ Wydział Filologiczny \\ Uniwersytet w Białymstoku \\ e-mail: ka.sias@wp.pl
}

\title{
Etnicyzacja miejskiej przestrzeni na przykładzie utworów Sokrata Janowicza i Miry Łukszy
}

Analiza twórczości podlaskich Białorusinów prowadzi do wniosku, że tym, co determinuje zarówno kreacje bohaterów, jak też ich sposób bycia w mieście, „punkt widzenia” (także punkt widzenia narratora) oraz sam obraz Białegostoku jest w dużej mierze etniczność: jawna, pseudonimowana czy potencjalna (bo już wyparta w procesie polonizacji bądź samopolonizacji albo jeszcze nieuświadomiona, zaklęta w wiejskości). Jak zauważa Eugenia Prokop-Janiec:

Badanie etnicznego wymiaru literatury [...] prowadzi [...] do takiego przeformułowania kategorii poetyki, które uwzględnia ich historyczne i kulturowe uwarunkowania i sensy. Przykładem tego typu zabiegów może być redefinicja „punktu widzenia" rozumianego już nie tylko jako kategoria narracyjna, ale też etnologiczna, to jest odnosząca się do doświadczenia i zakorzenienia kulturowego, manifestująca kulturową tożsamość i kulturowy dystans ${ }^{1}$.

Małgorzata Czermińska, analizując „punkt widzenia” jako kategorię antropologiczną w prozie niefikcjonalnej, skupiła się - jak sama zadeklarowała, „dla bardziej przejrzystego przedstawienia problemu" - na sytuacjach „zetknięcia się różnych kręgów kulturowych”2, z pominięciem podmiotów

1 E. Prokop-Janiec, Etniczność, w: Kulturowa teoria literatury, red. M.P. Markowski, R. Nycz, Kraków 2002, s. 424.

2 M. Czermińska, „Punkt widzenia” jako kategoria antropologiczna i narracyjna w prozie niefikcjonalnej, „Teksty Drugie” 2003, nr 2-3, s. 12. 
o tożsamości bardziej złożonej, na przykład dietnicznej, scharakteryzowanej przez Elżbietę Smułkową. Definiując ten typ tożsamości, badaczka wychodzi od analiz zachowań językowych mieszkańców Podlasia, wśród których wyróżnia bilingwizm z dyglosją. Mamy z tym zjawiskiem do czynienia wtedy, gdy zasady użycia dwóch (lub więcej) języków zostały ukształtowane społecznie i trwają od kilku pokoleń. Będzie to np. sytuacja, gdy:

gwara obsługuje sferę życia prywatnego, rodzinno-sąsiedzkiego, zaś do kontaktów zewnętrznych, $\mathrm{z}$ obcym przybyszem lub osobami stojącymi wyżej $\mathrm{w}$ hierarchii społecznej (np. nauczyciel ze szkoły polskiej, ksiądz katolicki, lekarz, urzędnik itp.), używa się języka polskiego ${ }^{3}$.

Dyglosji, która jest pojęciem odnoszącym się do przypadków indywidualnych, w społecznym wymiarze odpowiada dietnia:

Pojęcie dietni, jak sądzę, nadaje się do opisu białoruskiej sytuacji lingwokulturowej, zarówno w sensie regionalnym, jak i ogólnokrajowym. Przede wszystkim dlatego, że głębokie przeniknięcie do kultury białoruskiej elementów innych kultur, zwłaszcza polskiej i rosyjskiej, ma od wielu pokoleń charakter spoleczny ${ }^{4}$.

Tym bardziej komplikuje to przejawianie się etnicznej odrębności Białorusinów w literaturze. Także na tym polu bywają z różnych względów dwujęzyczni (np. dla zwiększenia zasięgu recepcji swoich dzieł czy z powodów komercyjnych).

Z ustaleń Czermińskiej wynika, że żadne podmiotowe spojrzenie nie jest „etnicznie niewinne”, neutralne, nawet jeśli różnice czy konflikty kulturowe nie są tematyzowane. Nie jest tak oczywiście również w przypadku polskości na Podlasiu, wydaje mi się jednak, że w sytuacji, gdy nacja stanowi większość, można (nawet jeśli to działanie pozorne) wyabstrahować jednostkowe doświadczenie $\mathrm{z}$ etnicznego kontekstu. Bohater literacki polskiej prozy może zwyczajnie kochać i wspominać, bohater np. Sokrata Janowicza będzie kochał i wspominał jako Białorusin. Bogdan Dudko dzielił się z Janowiczem na łamach „Kartek” spostrzeżeniem, że dialog z młodymi Białorusinami jest trudny, bo jakiegokolwiek tematu by nie dotyczył („poezja”, „miłość", „życie”), zawsze ostatecznie wybrzmi jako „kwestia białoruska”. Pisarz bynajmniej nie zaprzeczył - tak właśnie jest, kiedy naród egzystuje w stanie zagrożenia, w sytuacji "oblężonej twierdzy":

${ }^{3}$ E. Smułkowa, Białoruś i pogranicza. Studia o języku i społeczeństwie, Warszawa 2002, s. 416.

4 Tamże, s. 420. 
To jest skutek poczucia zagrożenia istnienia w ogóle narodowości białoruskiej. Jest to smutne, choć zrozumiałe, bo ta młoda inteligencja, czując śmiertelne tchnienie, nie jest otóż psychologicznie w stanie rozmawiać na tematy zasadnicze. Ona zawsze, jak gdyby, będzie chora na białoruskość. Jak obłożnie chory człowiek, którego niewiele obchodzą sprawy tego świata, bowiem walczy ze śmiercią własną ${ }^{5}$.

Warto potraktować to jako sugestię wzmożonej czujności wobec pisanych przez Białorusinów tekstów, nawet jeśli w warstwie zewnętrznej, na poziomie deklaratywnym, zdają się „kwestii białoruskiej” nie dotyczyć.

W prozie Sokrata Janowicza etniczne nacechowanie przekłada się między innymi na sposób obrazowania i waloryzowania miejskiej przestrzeni. Posiłkując się sformułowaniem Katarzyny Szalewskiej, nawiązującym do refleksji Michela de Certeau, można powiedzieć, że w opisujących wędrówki po Białymstoku tekstach Janowicza dokonuje się „interpretacyjny ruch od anegdoty-spaceru po mieście ku społecznym kodom i modelom działań symbolicznych - miasta jako parametru biografii i jako teatru historii" ${ }^{6}$. Jak zauważa Szalewska:

Miasto dotknięte przez historię, wojenne $\mathrm{i}-\mathrm{w}$ innym sensie - PRL-owskie, jakie wyłania się z lektury polskiej literatury XX stulecia, jest zawsze spotkaniem narracji ideologicznego $\mathrm{z}$ narracją jednostkowego, mapy $\mathrm{z}$ nierespektującymi jej praktykami podmiotu, który wyznacza trasy własnej biografii ${ }^{7}$.

W przypadku Janowicza „świadomość ideologicznego uwikłania miejskiej przestrzeni" wydaje się punktem wyjścia jej obrazowania. Ze względu na specyficzną genealogię bohaterów tej prozy, przyjeżdżających do Białegostoku z okolicznych wsi, obecność w mieście, zwłaszcza w jego centrum ${ }^{8}$, nieważne, czy relacjonowana bezpośrednio, czy z czasowego dystansu, nabiera charakteru subwersywnego „mapowania”, na które składają się we-

5 S. Janowicz, Literatura to nie PZU, rozm. B. Dudko, J. Turonek, „Kartki” 1995, nr 11, s. 24.

6 K. Szalewska, Antropologia przestrzeni miejskiej w kontekście polskiego dyskursu postzależnościowego, w: (P)o zaborach, (p)o wojnie, (p)o PRL. Polski dyskurs postzależnościowy dawniej i dziś, red. H. Gosk, E. Kraskowska, Kraków 2013, s. 352.

7 Tamże, s. 350.

8 Symbolika centrum i peryferii miejskich w kulturze europejskiej jest oczywista, zwięźle, choć ironicznie ujął ją Roland Barthes: „stosownie do ruchu metafizyki zachodniej, dla której każde centrum jest miejscem prawdy, centrum w naszych zachodnich miastach jest zawsze pełne: miejsce naznaczone; to w nim zbierają się i streszczają wartości cywilizacji: duchowość (kościoły), władza (urzędy), pieniądz (banki) i handel (wielkie sklepy), słowo (agory: kawiarnie i promenady); iść do centrum - to spotkać «prawdę» społeczną, to uczestniczyć we wspaniałej pełni «rzeczywistości»" [R. Barthes, Imperium znaków, przeł. A. Dziadek, Warszawa 1999, s. 82]. 
dług Katarzyny Szalewskiej różne rodzaje „praktyk” topograficznych, służących symbolicznej reorganizacji przestrzeni. Nawet jeśli tą praktyką będzie promenowanie, związane u swojej genezy z wiekiem XIX i nowoczesnością („promenować oznacza przechadzać się po centralnym punkcie miasta i odgrywać w nim teatr międzyludzkich relacji”) czy „rytmoanaliza” (za Henri Lefebvrem - dostrajanie się do rytmu miasta: nuworysze chcą się w nie przecież wtopić), fakt, że robią to „wieśniacy", potencjalnie - Białorusini, przydaje tym działaniom charakter wpisanej w istotę "mapowania" „topograficznej herezji, a więc zamierzonego błędu popełnianego w języku urbanistyki" 9 . Subwersywna jest niejako sama ich obecność w tych miejscach.

Szalewska nawiązuje tu oczywiście ponownie do propozycji de Certeau, czyniącego rozróżnienie na "gramatykę" miasta i indywidulane "retoryki" jego użytkowników ${ }^{10}$. W przypadku powstającej na Podlasiu białoruskiej literatury, „używającej” miejskiej przestrzeni jako scenerii czy miejsca akcji, sprawa się komplikuje, gdyż "gramatyka" Białegostoku została, gdy był on podnoszony z gruzów po 1945 roku, napisana po polsku, co więcej, hiperpoprawnie (niepewne poczucie własnej polskości czy katolickości to trwały kompleks białostoczan; Ignacy Karpowicz nazywa to „arcypolskością"), z hermetycznymi enklawami przewidzianymi na działania mniejszości czy punktami - takimi, jak cerkwie - które można łatwo wydzielić z miejskiej tkanki. A przecież - jak usłyszeć możemy od samych Białorusinów - oni też są tu "od zawsze" i czują się, na równi z Polakami, gospodarzami tych ziem, razem z nimi też, jako wiejscy migranci, zasiedlili stolicę regionu.

Spektakl odgrywany w centrum Białegostoku, nawet jeśli nosi znamiona mimikry, pozostaje zatem aktem demonstrowania swojej obecności i prawa do tej - kluczowej dla miejskiej autonarracji - przestrzeni. Oto „białoruscy wieśniacy” wytyczają własne ścieżki na trotuarach „wielkiego miasta”, nie ograniczając się bynajmniej do jego peryferii i, zgodnie z prawem mimikry, naśladując "miejskość” i "polskość”, dekonstruują je. Jak zauważa Szalewska, dla rozważań nad literaturą najbardziej interesujący jest mediatyzowany za pośrednictwem zapisu

\footnotetext{
${ }^{9}$ K. Szalewska, Retoryka bycia-w-mieście. Figury przestrzeni i myśli, w: Nowe poetyki miejskie. Z problematyki urbanistycznej w literaturze XX $i$ XXI wieku, red. M. Roszczynialska, K. Wądolny-Tatar, Kraków 2015, s. 31-32. Szalewska rozróżnia tu tradycyjne „promenowanie” (czyli właśnie spacery-spektakle po centrum miasta, jak w Ziemi obiecanej Władysława Reymonta), od współczesnych, odrzucających „istotne dla tej praktyki przestrzenne opozycje: centrum peryferie, wnętrze - zewnętrze, kobiece - męskie, prywatne - publiczne" [tamże, s. 33].

10 Zob. M. de Certeau, Mowa błądzacych kroków, w: tegoż, Wynaleźć codzienność. Sztuki dziatania, przeł. K. Thiel-Jańczuk, Kraków 2008, s. 98 i nast.
} 
proces wytwarzania miasta przez przestrzenie władzy, symboliki, pamięci; akty dopisywania i eliminacji elementów miejskiej tkanki w pozycji zależnościowej i emancypacyjnej. Kryje się w tym również podmiotowa perspektywa, sprzeciwiająca się miastu jako idei polityczno-urbanistycznej i wprowadzająca w jego przestrzeń jednostkową opowieść ${ }^{11}$.

Taką właśnie, choć również zideologizowaną, tyle że z pozycji zależnościowych/emancypacyjnych, „jednostkową opowieść" (acz reprezentatywną dla mniejszościowej zbiorowości) wpisuje w przestrzeń Białegostoku Sokrat Janowicz. Byłby to rodzaj - tworzę ten neologizm na wzór „psychogeografii" 12 - „etnogeografii” miasta, zaś do wyróżnionych przez Szalewską rodzajów „mapowania” proponuję dołączyć „etnicyzację”. Polega ona na tym, że na „polską” mapę nanosi się „,białoruskie ślady i znaki” "13: "punkt widzenia" (razem z nim świat odniesień i wyobrażeń, np. ulica jako wiejska droga, którą bogaci jadą samochodem/wozem, a biedni idą ${ }^{14}$, sposób postrzegania lub wręcz niedostrzeganie pałacu Branickich ${ }^{15}$ ), akcent, zdradzający niepolskie pochodzenie, imiona, jakie noszą postaci (Wiera, Tania, Kola itd.), cyrylicę (może być ukryta w przechowywanej w domu encyklopedii ${ }^{16}$ albo zamknięta w getcie pod nazwą „prasa mniejszości”). Nie zgadzam się ze stwierdzeniem Heleny Duć-Fajfer, że „Janowiczowski nuworysz «z wiechciem w bucie»" ${ }^{\prime 17}$ :

11 K. Szalewska, Antropologia przestrzeni miejskiej w kontekście polskiego dyskursu postzależnościowego, s. 350.

12 E. Konończuk, Psychogeograficzne poetyki miejskie, w: Nowe poetyki miejskie. Z problematyki urbanistycznej w literaturze XX $i$ XXI wieku, s. 20-27.

13 Taki tytuł: Ojczystość. Białoruskie ślady i znaki nosi opracowany przez Roberta Trabę zbiór tekstów Sokrata Janowicza (Olsztyn 2001).

14 „Na chodniku - mężczyźni i kobiety, chłopcy i dziewczęta, dzieci. Chodzą. Ulicą jadą samochody osobowe, a w nich ci, którzy nie mają potrzeby wygłupiać się chodzeniem pieszo. Wszystko to wyglądało trochę tak, jakby w czasie żniw pociemniały chmury nad Długim Wygonem i wtedy bogaci powsiadali na wozy, zaczęli uciekać środkiem drogi. A Jurka z matką schowali sierpy w rozkraczony dwunastek i pobiegli do domu ścieżką, skrajem kolein. Z wozów krzyczano do nich, żeby szybciej biegli, bo zmokną... To był żart..." [S. Janowicz, Tania, przeł. A. Sobecka, w: tegoż, Małe dni, Warszawa 1981, s. 173].

15 Zob. np. opis wystawy rolniczej urządzonej wzdłuż muru otaczającego pałac Branickich (symbol magnackiej przeszłości Białegostoku, założonego jako miasto prywatne) [S. Janowicz, Dolina petna losu, Białystok 1993, s. 72 i nast.].

16 Bohater powieści Samosiej Andrzej „Zapalił lampkę nocną, w białoruskiej encyklopedii znalazł hasło o wilku..." [S. Janowicz, Samosiej, przeł. J. Plutowicz, Warszawa 1981, s. 248].

17 H. Duć-Fajfer, Pomiędzy bukwa a litera. Wspótczesna literatura mniejszości białoruskiej, ukraińskiej i łemkowskiej w Polsce, Kraków 2012, s. 202. 
Określony jest ściśle warunkami swego awansu, który go ukształtował i wciągnął w mechanizm odpowiednich działań i konwencji. Generalnie kształtuje go przestrzeń awansu i ustalone w niej hierarchie ważności i statusu społecznego. Jest ona przez niego już pragmatycznie oswojona, zna jej reguły i ma wypracowane strategie zachowań wobec tego, co może przedostawać się tu z jego przestrzeni rodowej i co może go ewentualnie spotkać w wyniku kolejnego stopnia awansu, którego się spodziewa. Nie jest to zatem przestrzeń unheimlich, ale nie jest to też przestrzeń wkorzenienia i usensownienia. On w niej działa i przemieszcza się powierzchownie, nie rozróżnia centrum ani kierunków wartościujących. Błąkanie się, przypadkowość, fragmentaryczność, pustka pomimo natłoku elementów to doznania, które nasuwają skojarzenia z Auge'owskimi nie-miejscami, jeśli chodzi o sposób bycia i zachowania się w przestrzeni ${ }^{18}$.

Wydaje mi się, że bohaterowie tej prozy, przeciwnie - właśnie jako gorliwi nuworysze - bardzo szybko zaczynają świetnie się orientować w miejskiej przestrzeni i regułach jej wartościowania, a to, co Duć-Fajfer określa mianem „błąkania się" jest raczej „dryfowaniem”, poddawaniem się rytmowi miasta, by się z nim oswoić. Bohater Wielkiego miasta Białystok, utworu, do którego przede wszystkim odnoszą się rozważania Duć-Fajfer, nie błądzi, tylko zatacza koło, zakreśla swoją wędrówką krąg wokół ścisłego centrum, niejako biorąc je w swoje posiadanie. Czytając to opowiadanie zawsze mam też poczucie, że Jerzemu przypisany został jakiś rodzaj władzy, wyższości, wtajemniczenia. Takie wrażenie ewokuje scena ekspozycji, gdy uprzywilejowane zostają jego punkt widzenia i perspektywa - stoi wprawdzie na chodniku, zatem na tej samej wysokości, co obserwowani przechodnie, zdaje się jednak dysponować „boskim okiem”. Prawdopodobnie też nie przypadkiem ma za plecami ratusz - symboliczną siedzibę władz miejskich; w realnej przestrzeni Białegostoku miejsce to znajduje się na lekkim wzniesieniu, co dodatkowo wzmacnia efekt spojrzenia "z góry”. Mamy tu do czynienia z intrygującą grą upodrzędnienia (kontekst społeczny, etniczny) i przewagi.

Wszystko to wydaje się tym bardziej fascynujące, że białoruskie mapowanie, $z$ racji hierarchicznych relacji mniejszość/większość, nieustającego (nieważne, na ile uzasadnionego) poczucia zagrożenia, właściwej mniejszościom czujności i ostrożności (jeden z jej przejawów to skłonność do mowy ezopowej czy narracji parabolicznych), czyli artykułowania swojej tożsamości w cieniu polskości (o czym pisze Duć-Fajfer), odbywa się w sposób niejawny, dyskretny, nieustannie oscylując między ostentacją (musi być przecież

18 Tamże, s. 203-204. 
dostrzeżone) a kamuflażem. Stawia to duże wymagania odbiorcy, występującemu w roli tropiciela znaków, które mogą być nieczytelne dla osób niewtajemniczonych czy choćby niewyczulonych na białoruskie niuanse. Za przykład niech posłuży wiersz Miry Łukszy Leon:

Idę białym miastem.

Białe skrzydła mi rosną,

wykluwają się pod czerwoną koszulą,

wieją w twarze przechodniów,

spocone, ślepe. Wykluwają się oczy.

Wykluwają się ludzie. Wilgotne kolory.

Wieje mi $\mathrm{w}$ twarz zielony wiatr,

czerwony, żółty i błękitny. Krople

na suchym piasku. Pot olejny w bruzdach.

Wykluwają się trawy. Wykluwają się palce.

Czerwone. Stygmaty na białym

płótnie. Ukrzyżowany cień ptaka w locie

przemknął po niwie, po mnie. Po mnie. Już.

Wykluło się mgnienie i stało się wczoraj.

I tu wczoraj ziemia. Słońce. Wiatr. I cienie.

I po mnie ${ }^{19}$.

Nie jest bynajmniej oczywiste, że tytułowy Leon to Leon Tarasewicz, jeden z najwybitniejszych białoruskich artystów plastyków, ale też już od czasów studenckich (urodził się w latach 50. XX wieku) czołowy aktywista podlaskiego ruchu białoruskiego. Nie ułatwia nam też identyfikacji zdjęcie, zamieszczone bezpośrednio pod wierszem - tym bardziej może rodzić poczucie dyskomfortu, że wkraczamy w jakąś familiarną, półprywatną przestrzeń (rodzinny album?) ludzi, którzy znają się na tyle dobrze, że nie muszą podpisywać swoich fotografii. Autorka czyni gest wobec postronnych czytelników, umieszczając to nazwisko $\mathrm{w}$ spisie treści, tyle że ulokowanym na końcu zbioru (nie musimy tam zatem zajrzeć przed lekturą). Zidentyfikowawszy malarza i właściwy mu styl (znak rozpoznawczy Tarasewicza to kolorowe pasy umieszczane $\mathrm{w}$ różnych konfiguracjach przestrzennych, których barwy wywodzą się z podlaskich pejzaży), zrozumiemy obecność kolorów czy "potu olejnego" w wierszu, odsyłającego zarówno do farb olejnych, jak i do rzepaku porastającego pola w rodzinnych okolicach Tarasewicza czy też do świętych olejów. Jednak aby jeszcze wnikliwiej odczytać ten tekst, musimy dysponować wiedzą, że czerwień i biel, ewidentnie w nim eksponowane, nie tylko przez powtórzenie („białe skrzydła mi rosną, wykluwają się pod

19 M. Łuksza, Leon, w: tejże, Wiersze tutejsze, Białystok 2003, s. 28. 
czerwoną koszulą"; „Czerwone. Stygmaty na białym płótnie”) to kolory flagi narodowej, jaką posługuje się białoruska opozycja. Tę ukrytą, zamaskowaną flagę obnosi Leon po „białym” mieście, które Łuksza tak opisuje w tomie Biały stok:

Idę przez białe miasto otwieram skrzydła ramion. Tu jeszcze choć na moment nie zgadniesz, jaki mur wyrósł właśnie za rogiem ze zunifikowanych cegieł, czy ta maska to twarz odarta z osobistej skóry, czy ta twarz jest maską. Wszystkie kolory spektrum światła widzialnego mamy w młodych skrzydłach i starych oczach ${ }^{20}$.

Dzieje się tak, jakby w późniejszym o niemal dekadę utworze doszło do połączenia feerii ostrych, podstawowych barw (czerwień, żółć, zieleń), jaką skrzył się wiersz poświęcony Leonowi Tarasewiczowi - biel to przecież kolor powstający w efekcie ich zmieszania. Ma to oczywiście ambiwalentną wymowę: z jednej strony może oznaczać bezkonfliktową koegzystencję tego, co różnorodne (także etnicznie) w „białym” mieście, wzajemną szczerość i otwartość ${ }^{21}$, z drugiej - unifikację, utratę właściwości. Tę niejednoznaczność podkreśla struktura temporalna wiersza, fundowana przez partykułę "jeszcze”, odsuwającą w czasie sytuację, gdy "twarzy” nie można będzie odróżnić od "masek”, a ze „zunifikowanych cegieł” wyrosną dzielące ludzi mury. Jak to $w$ literaturze bywa, orzeczenie o świecie przez zaprzeczenie, negację czy tryb warunkowy nie traci swej performatywnej mocy - widmo takiego „białego" (tym razem groźną, upiorną, może nawet trupią bielą) miasta zostaje w przez Łukszę wywołane. Danuta Zawadzka interpretuje ten utwór w kontekście całego tomu, którego sensy, w rzeczy

\footnotetext{
20 M. Łuksza, Białystok, w: tejże, Biały stok, Warszawa 2012, s. 6.

21 Pozytywny aspekt bieli potwierdza wypowiedź poetki, pochodząca w wywiadu udzielonego tuż po ukazaniu się tomiku: „Białystok to bardzo młode miasto. W moim odczuciu ludzie są tu szczerzy - nie noszą na twarzach masek, za pomocą których chcieliby się przed kimś ukryć" [M. Łuksza, Białystok to biały potok, rozm. T. Mikulicz, „Kurier Poranny” 23.01.2013 r., http://www.poranny.pl/magazyn/art/5509230,mira-luksza-bialystok-to-bialy-potok,id,t.html, dostęp 12.11.2017].
} 
samej, jak chce badaczka, ufundowane zostały w dużej mierze na „białoruskiej wrażliwości na biel" 22, zrozumiałej - mówiąc w dużym uproszczeniu, po szczegóły odsyłam do cytowanego artykułu - ze względów etymologiczno-kulturowych:

Tym razem autorka wykorzystuje metaforykę optyczną i świetlną, walory bieli jako „wszystkich kolorów spektrum”. Tak pokazana zapowiada pełnię możliwości, skojarzoną w wierszu z młodością i skrzydłami, ale jednocześnie jest barwą „unifikującą": „wszystkimi” i żadną, wręcz od-barwieniem. „Białe miasto" z incipitu może więc być obietnicą i marzeniem, ale - jak zwykle $\mathrm{w}$ tym tomiku - jego futurystyczna orientacja ma ambiwalentną wymowę, bo „zunifikowane cegły" ukrywają jakąś dramatyczną przedakcję, utratę: zrujnowanie Białegostoku po II wojnie światowej, socrealistyczne zniszczenie dawnej, drewnianej architektury miasta [...] czy, w porządku biograficznym - konieczność opuszczenia domu „na fundamencie z kamieni” [czyli wiejskiego - dop. K.S.M.]. Puenta utworu potwierdza tę ambiwalencję paralelą domyślnie białych "młodych skrzydel” z wyblakłą barwą "starych oczu”, pełni z pustką, nadziei z melancholią 23 .

Z perspektywy moich rozważań najważniejsze wydaje się, że niezwykle istotny dla wszelkich interpretacji tego typu utworów jest kontekst etniczny, który wpływa zarówno na sposób widzenia przestrzeni i miejsc, jak też na poetykę i środki wyrazu użyte do ich zobrazowania, czyniąc je częścią "konstelacji hybrydowej” - specyficznego układu nadawczo-odbiorczego. Kategoria ta pojawia się w artykule Brigitte Schultze w odniesieniu do twórców mieszkających w co najmniej dwóch państwach i piszących w co najmniej dwóch językach dla odbiorców pochodzących z różnych kręgów kulturowych (autorka odnosi się do pisarzy czeskich, którzy kierują swoje teksty do rodzimych bądź też niemieckich czytelników $\left.{ }^{24}\right)$. Specyfika Białegostoku i Podlasia polega na tym, że ten "hybrydowy” układ staje się „konstelacją" wewnątrzregionalną, a odczytanie generowanych w jego ramach treści wymaga specyficznych kompetencji czytelniczych - kulturowy idiom wyłącznie polski czy też wyłącznie białoruski okazuje się tu niewystarczający.

\footnotetext{
22 D. Zawadzka, Białystok jak buza. Do „białej” imagologii regionu podlaskiego, w: Geografia wyobrażona regionu. Literackie figury przestrzeni, red. D. Kalinowski, M. Mikołajczak, A. Kuik-Kalinowska, Kraków 2014, s. 209.

23 Tamże, s. 212.

24 B. Schultze, Konstelacje hybrydowe a tożsamość narodowa: proza Jaroslava Rudiša (2002-2013) i Olgi Martynowej (2013), przeł. M. Klukowska i M. Skwara, w: Narodowe, regionalne, kontynentalne, światowe - literatury i dyskursy o literaturach, red. M. Skwara, Kraków 2017, s. 69-87.
} 


\section{Bibliografia}

Barthes Roland, Imperium znaków, przeł. A. Dziadek, Warszawa: Wydawnictwo KR, 1999.

Czermińska Małgorzata, „Punkt widzenia” jako kategoria antropologiczna i narracyjna w prozie niefikcjonalnej, „Teksty Drugie” 2003, nr 2-3, s. 11-27.

Certeau de Michel, Wynaleźć codzienność. Sztuki działania, przeł. K. Thiel-Jańczuk, Kraków: Wydawnictwo UJ, 2008.

Duć-Fajfer Helena, Pomiędzy bukwą a literą. Współczesna literatura mniejszości białoruskiej, ukraińskiej i łemkowskiej w Polsce, Kraków: Wydawnictwo UJ, 2012.

Janowicz Sokrat, Dolina pełna losu, Białystok: Orthdruk, 1993.

Janowicz Sokrat, Literatura to nie PZU, rozm. B. Dudko, J. Turonek, „Kartki” 1995, nr 11, s. 22-25.

Janowicz Sokrat, Małe dni, Warszawa: Czytelnik, 1981.

Janowicz Sokrat, Samosiej, przeł. J. Plutowicz, Warszawa: Ludowa Spółdzielnia Wydawnicza, 1981.

Konończuk Elżbieta, Psychogeograficzne poetyki miejskie, w: Nowe poetyki miejskie. Z problematyki urbanistycznej w literaturze XX i XXI wieku, red. M. Roszczynialska, K. Wądolny-Tatar, Kraków: Wydawnictwo Naukowe UP, 2015, s. 20-27.

Łuksza Mira, Biały stok, Warszawa: IBIS, 2012.

Łuksza Mira, Białystok to biały potok, rozm. T. Mikulicz, „Kurier Poranny” 23.01.2013 r., http://www.poranny.pl/magazyn/art/5509230,mira-luksza-bialystok-to-bialypotok,id,t.html [dostęp 12.11.2017 r.].

Łuksza Mira, Wiersze tutejsze, Białystok: Biblioteka „Kartek”, 2003.

Prokop-Janiec Eugenia, Etniczność, w: Kulturowa teoria literatury, red. M.P. Markowski, R. Nycz, Kraków: Universitas, 2002, s. 409-432.

Schultze Brigitte, Konstelacje hybrydowe a tożsamość narodowa: proza Jaroslava Rudiša (2002-2013) i Olgi Martynowej (2013), przeł. M. Klukowska i M. Skwara, w: Narodowe, regionalne, kontynentalne, światowe - literatury i dyskursy o literaturach, red. M. Skwara, Kraków: Universitas, 2017, s. 69-87.

Smułkowa Elżbieta, Białoruś i pogranicza. Studia o języku i społeczeństwie, Warszawa: Wydawnictwa UW, 2002.

Szalewska Katarzyna, Antropologia przestrzeni miejskiej w kontekście polskiego dyskursu

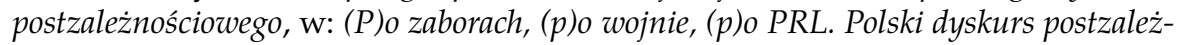
nościowy dawniej i dziś, red. H. Gosk, E. Kraskowska, Kraków: Universitas, 2013, s. 345-362.

Szalewska Katarzyna, Retoryka bycia-w-mieście. Figury przestrzeni i myśli, w: Nowe poetyki miejskie. Z problematyki urbanistycznej w literaturze XX i XXI wieku, red. M. Roszczynialska, K. Wądolny-Tatar, Kraków: Wydawnictwo Naukowe UP, 2015, s. 28-38.

Zawadzka Danuta, Białystok jak buza. Do „białej” imagologii regionu podlaskiego, w: Geografia wyobrażona regionu. Literackie figury przestrzeni, red. D. Kalinowski, M. Mikołajczak, A. Kuik-Kalinowska, Kraków: Universitas, 2014, s. 201-216. 


\section{Ethnicization of Urban Space in the Works by Sokrat Janowicz and Mira Łuksza \\ Summary}

The article interprets selected works of two Belarusian writers, Sokrat Janowicz and Mira Łuksza and concentrates on the concept of ethnic focalization. Drawing on the idea of urban "mapping", formulated by Katarzyna Szalewska, the author proposes one more strategy, namely ethinicization. This method seems indispensable in the topo-analysis of bi-ethnic regions, which evoke "hybrid constellations" between the author and the reader.

Keywords: urban space, ethnic focalization, bi-ethnic region, Sokrat Janowicz, Mira Łuksza 